Kinga Przybyszewska Państwowa Wyższa Szkoła Zawodowa w Koninie
Kiedy myślimy Rodzina..., red. M. Duda, K. Kułek-Sładek, Kraków 2016, s. 427-442 (Praca Socjalna w Teorii i Działaniu, 2).

\title{
Zakres wsparcia pomocy społecznej oferowanej rodzinom wielodzietnym i niepełnym w województwie mazowieckim
}

The field of help offered for the large families and one-parent family in the mazowieckie voivodship

\begin{abstract}
The field of help offered for the large families and one-parent family in the mazowieckie voivodship can be analysed included their aspects: financial support, material aid and helping family programs. Such a help could be considered when will be included the housing situation of the family, help guaranteed
\end{abstract}

because of they have got a children or the programs realized for them by different local government unit.

Keywords: social service, financial support, material aid, helping family programs

Pomoc rodzinom udzielaną w województwie mazowieckim można analizować, uwzględniając różne jej aspekty. Są to: pomoc finansowa, pomoc materialna oraz programy na rzecz wspierania rodzin. Wysokość środków wydatkowanych przez jednostki organizacyjne pomocy społecznej (JOPS) i ogólnie jednostki samorządu terytorialnego (JST) na poszczególne cele zaprezentowano w tabeli 1. Pozycje wydatków na rzecz rodzin wielodzietnych i niepełnych stanowią znaczną część budżetu JOPS i JST (same świadczenia rodzinne, świadczenia $\mathrm{z}$ funduszu alimentacyjnego oraz składki na ubezpieczenia emerytalne i rentowe $z$ ubezpieczenia społecznego stanowią prawie połowę 


\begin{tabular}{|c|c|c|c|c|c|c|c|c|c|c|}
\hline & 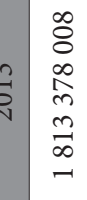 & 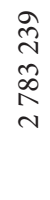 & $\begin{array}{l}1 \\
\delta \\
m \\
m \\
\infty \\
\infty\end{array}$ & 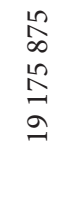 & 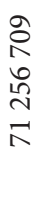 & $\begin{array}{l}\stackrel{2}{2} \\
\infty \\
\stackrel{2}{a} \\
\stackrel{\sim}{v}\end{array}$ & $\begin{array}{l}\frac{2}{R} \\
2 \\
2 \\
\hat{2} \\
k\end{array}$ & $\begin{array}{l}\exists \\
\text { J } \\
\text { ळે } \\
\text { - }\end{array}$ & 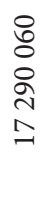 & 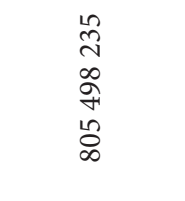 \\
\hline $\begin{array}{l}\frac{n}{1} \\
0 \\
\vdots \\
\vdots \\
3\end{array}$ & 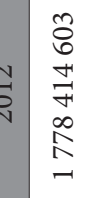 & $\begin{array}{l}\stackrel{0}{f} \\
\stackrel{2}{R} \\
\stackrel{N}{N}\end{array}$ & \begin{tabular}{l}
8 \\
$\infty$ \\
+ \\
\multirow{+}{+}{} \\
$\infty$ \\
$\infty$ \\
1
\end{tabular} &  & 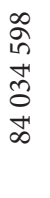 & $\begin{array}{l}\overrightarrow{8} \\
\infty \\
\infty \\
\infty \\
0 \\
\infty\end{array}$ & 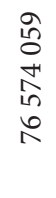 & 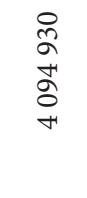 & 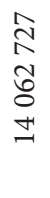 & 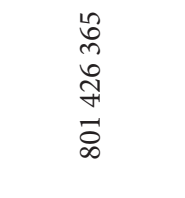 \\
\hline & 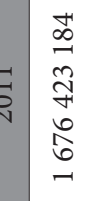 & 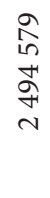 & 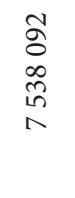 & 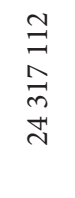 & $\begin{array}{l}\text { Na } \\
\text { ò } \\
\text { \&े } \\
\text { ñ }\end{array}$ & 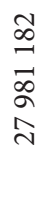 & $\begin{array}{l}0 \\
0 \\
0 \\
0 \\
0 \\
0 \\
0\end{array}$ & $\begin{array}{l}\vec{\infty} \\
\stackrel{N}{N} \\
\infty \\
\infty \\
m\end{array}$ & $\begin{array}{l}2 \\
\alpha \\
\infty \\
\stackrel{1}{\kappa} \\
\infty\end{array}$ &  \\
\hline & 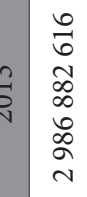 & 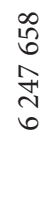 & 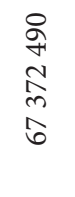 & 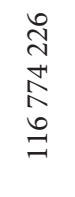 & 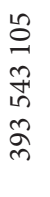 & 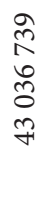 & $\begin{array}{l}\text { 웅 } \\
\vec{\delta} \\
\infty \\
\infty\end{array}$ & $\begin{array}{l}\stackrel{+}{N} \\
\stackrel{N}{N} \\
\stackrel{N}{N}\end{array}$ & 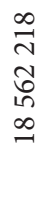 & $\begin{array}{l}10 \\
0 \\
0 \\
0 \\
0 \\
0 \\
0 \\
0 \\
-1\end{array}$ \\
\hline 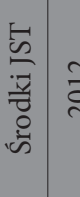 & 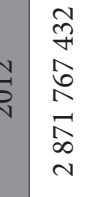 & 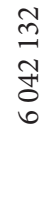 & \begin{tabular}{l}
$\exists$ \\
\multirow{4}{*}{} \\
$\stackrel{7}{7}$ \\
6 \\
6
\end{tabular} & 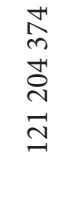 &  & $\begin{array}{l}\vec{\sim} \\
m \\
\tilde{n} \\
\stackrel{n}{n} \\
\stackrel{m}{+}\end{array}$ & $\begin{array}{l}\infty \\
0 \\
\tilde{N} \\
\infty \\
\infty \\
\infty \\
\infty\end{array}$ & $\begin{array}{l}\qquad \\
\infty \\
\infty \\
20 \\
\alpha \\
+\end{array}$ &  & $\begin{array}{l}\vec{b} \\
-1 \\
0 \\
0 \\
0 \\
20 \\
0 \\
-1\end{array}$ \\
\hline $\bar{c}$ & 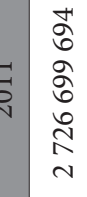 & 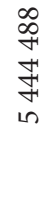 & 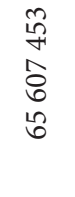 & 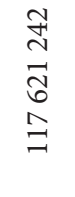 & 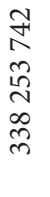 & $\begin{array}{l}\stackrel{m}{\sim} \\
\text { a } \\
\hat{\alpha} \\
\text { aे }\end{array}$ & $\begin{array}{l}\hat{\sigma} \\
\infty \\
\tilde{\sigma} \\
\hat{\sigma}\end{array}$ & $\begin{array}{l}\stackrel{ }{N} \\
\underset{N}{N} \\
+\end{array}$ & 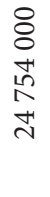 & 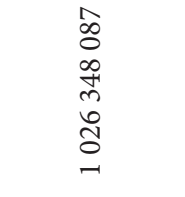 \\
\hline 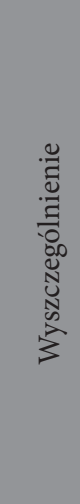 & $\begin{array}{l}\sum_{11} \\
\text { 崩 } \\
0 \\
0\end{array}$ & 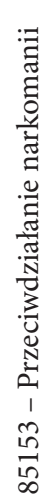 &  & 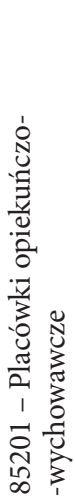 & 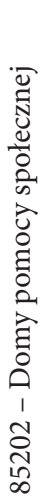 & 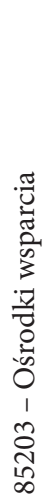 & 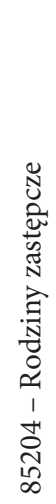 & 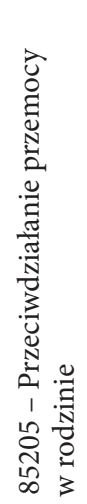 & 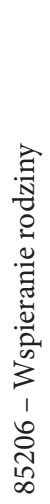 & 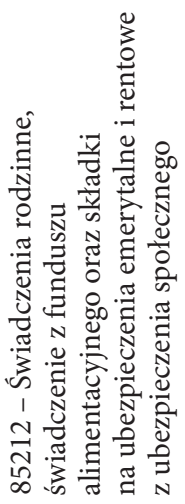 \\
\hline
\end{tabular}




\begin{tabular}{|c|c|c|c|c|c|c|c|c|c|}
\hline & 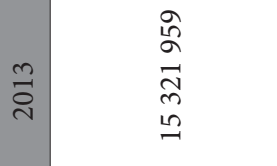 & 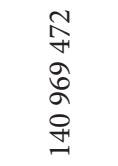 & 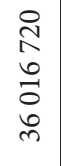 & 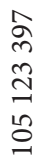 & 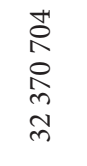 & 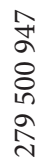 & $\begin{array}{l}\text { రू } \\
2 \\
\stackrel{m}{1} \\
m\end{array}$ & $\begin{array}{l}\overrightarrow{8} \\
\vec{m} \\
\text { मे }\end{array}$ & 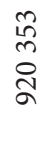 \\
\hline $\begin{array}{l}\text { 足 } \\
\frac{0}{0} \\
\text { ह1 } \\
3 \\
3\end{array}$ & 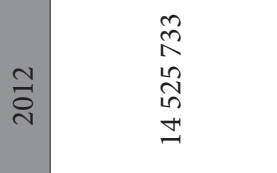 & 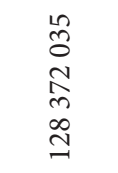 & $\begin{array}{l}2 \\
\stackrel{\infty}{ } \\
\hat{N} \\
\hat{n} \\
n \\
n\end{array}$ & 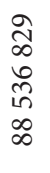 & $\begin{array}{l}\text { m } \\
\stackrel{\infty}{+} \\
\tilde{\infty} \\
\infty \\
\vec{m}\end{array}$ & 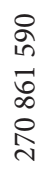 & $\begin{array}{l}\stackrel{n}{\wedge} \\
\vec{n} \\
\stackrel{\sim}{v}\end{array}$ & $\begin{array}{l}\stackrel{2}{2} \\
\stackrel{N}{N} \\
\text { if }\end{array}$ & 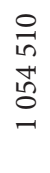 \\
\hline & $\begin{array}{l}\stackrel{2}{\Omega} \\
\text { in } \\
\stackrel{\sim}{\sim} \\
\stackrel{\sim}{\sim}\end{array}$ & 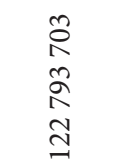 & $\begin{array}{l}2 \\
\delta \\
\infty \\
\infty \\
0 \\
\vec{m}\end{array}$ & 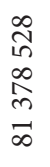 & 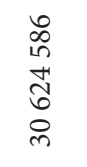 & 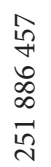 & $\begin{array}{l}\stackrel{0}{N} \\
\stackrel{N}{n} \\
\infty \\
\infty \\
\sim \\
\sim\end{array}$ & $\begin{array}{l}\stackrel{2}{\sigma} \\
\stackrel{2}{N} \\
\stackrel{\infty}{+}\end{array}$ & $\begin{array}{l}\text { 유 } \\
\hat{\alpha} \\
\infty\end{array}$ \\
\hline & 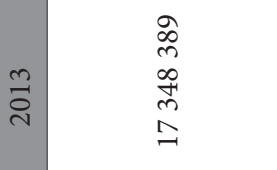 & 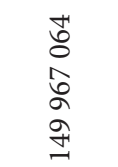 & $\begin{array}{l}m \\
\infty \\
1 n \\
10 \\
m \\
\infty \\
\infty\end{array}$ & 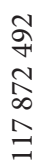 & 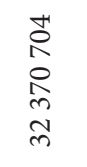 &  & 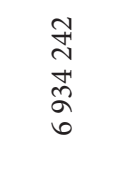 & $\begin{array}{l}\overrightarrow{\text { m}} \\
\text { v } \\
m \\
\text { in }\end{array}$ & 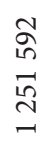 \\
\hline 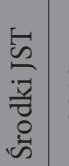 & 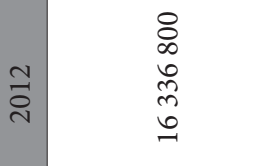 & 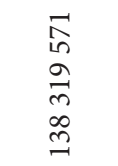 & 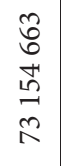 & 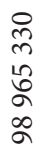 & $\begin{array}{l}\mathscr{m} \\
\infty \\
+ \\
\tilde{\infty} \\
\infty \\
\vec{m}\end{array}$ & 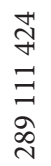 & 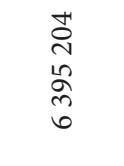 & 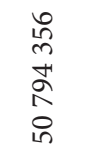 & $\begin{array}{l}\vec{\sigma} \\
\hat{2} \\
i n \\
-1\end{array}$ \\
\hline & 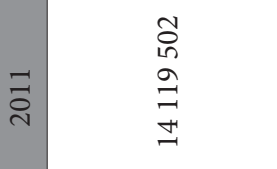 & 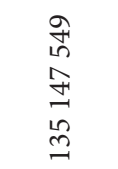 & 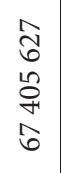 & $\begin{array}{l}\underset{\forall}{\sharp} \\
\stackrel{-}{\infty} \\
\infty \\
\infty\end{array}$ & 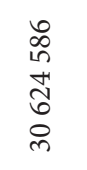 & 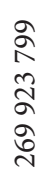 & $\begin{array}{l}\infty \\
\infty \\
\infty \\
\infty \\
\infty \\
\stackrel{+}{+} \\
\forall\end{array}$ & 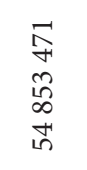 & 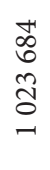 \\
\hline 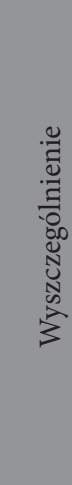 &  & 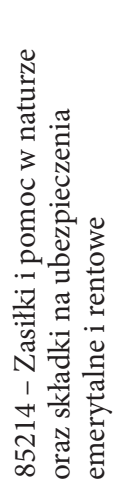 & 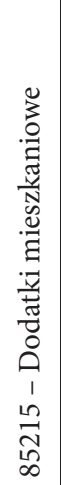 & 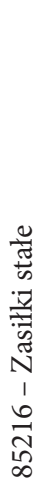 & 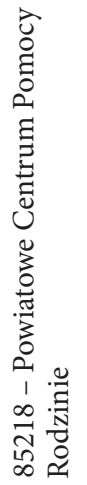 & 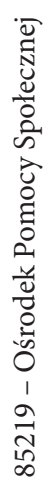 & 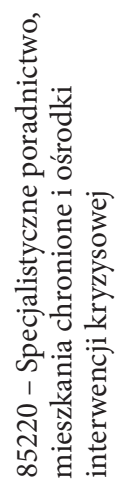 & 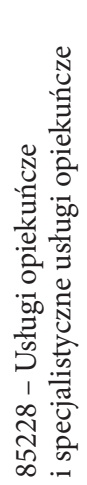 & 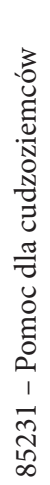 \\
\hline
\end{tabular}




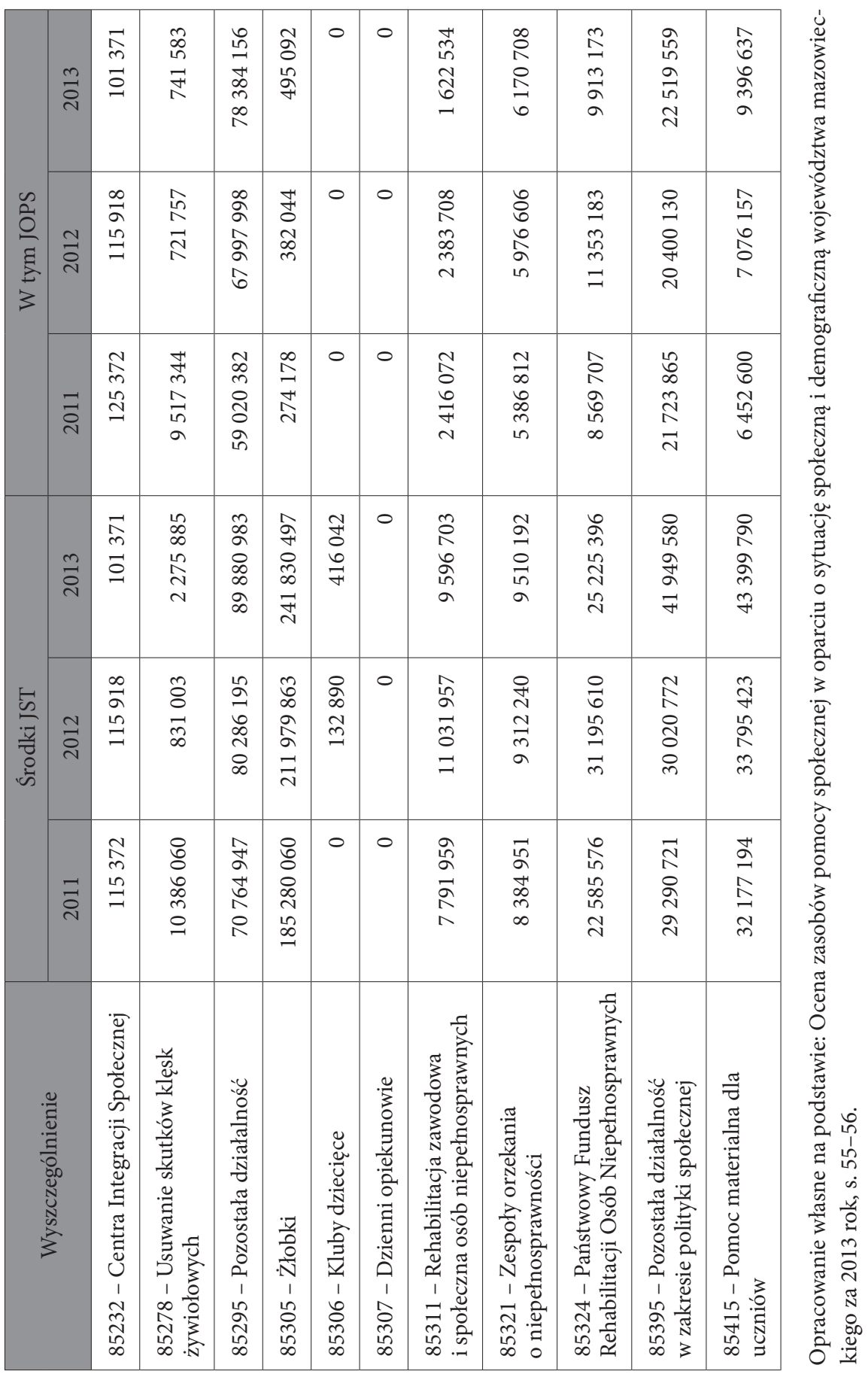


budżetu). Najważniejsze pozycje budżetu, dotyczące bezpośrednio rodzin wielodzietnych i niepełnych, omówione zostaną w dalszej części rozdziału.

Pomoc finansowa może być przyznawana rodzinom w postaci dofinansowań czy też zasiłków. Rodziny, które się usamodzielniają czy znalazły się w trudnej sytuacji, mogą liczyć na pomoc ze strony państwa w postaci dofinansowania czy też dodatku mieszkaniowego. Rodziny posiadające dzieci mogą też liczyć na pomoc finansową w postaci różnych zasiłków, świadczeń, czy też Karty Dużej Rodziny.

Jedną z form pomocy finansowej przyznawanej na usamodzielnienie się rodzin jest program Mieszkanie dla Młodych. Program zakłada pomoc w dofinansowaniu wkładu własnego. Dodatkowo rodziny, w których pojawi się trzecie dziecko własne bądź przysposobione w ciągu pięciu lat od dnia zakupu mieszkania, mogą liczyć na pomoc we wcześniejszej spłacie części kapitału kredytu. Również osoby, które rozpoczną budowę pierwszego własnego mieszkania, mogą otrzymać pomoc ze strony państwa. Osoby te będą mogły na nowych zasadach skorzystać z tzw. częściowego zwrotu VAT na materiały budowlane. Skorzystanie z programu Mieszkanie dla Młodych jest uzależnione od spełnienia wielu warunków, w tym takiego, że cena mieszkania nie może przekroczyć wskaźnika określonego dla danej lokalizacji ${ }^{1}$.

Wykres 1. pokazuje zmianę wartości tego wskaźnika dla miasta Warszawy, gmin przylegających do niej (Izabelin, Jabłonna, Józefów, Konstancin-Jeziorna, Lesznowola, Łomianki, Marki, Michałowice, Nieporęt, Ożarów Mazowiecki, Piaseczno, Piastów, Raszyn, Stare Babice, Sulejówek, Wiązowna, Ząbki i Zielonka) oraz pozostałych miast województwa mazowieckiego w poszczególnych kwartałach 2014 roku. Z wykresu 1. wynika, że cena $1 \mathrm{~m}^{2}$ mieszkania w pierwszym kwartale 2014 roku wynosiła dla miasta Warszawy 5864,70 zł, dla gmin do niej przylegających było to $4404,80 \mathrm{zł}$, zaś dla pozostałych miast województwa mazowieckiego - 3670,70 zł. W II kwartale 2014 roku limit dla Warszawy wynosił 6126,90 zł, dla gmin do niej przylegających było to 4457,50 zł, zaś dla pozostałych miast województwa mazowieckiego - 3714,60 zł. W III kwartale 2014 roku wartość wskaźników nie uległa zmianie. W IV kwartale 2014 roku limit dla Warszawy został określony w wysokości 6583,10 zł, dla gmin do niej przylegających było to $4596,80 \mathrm{zl}$, zaś dla pozostałych miast województwa mazowieckiego - 3830,60 zł. Oznacza to, że limity w województwie mazowieckim są regularnie podwyższane ${ }^{2}$. Wartość wykorzystanego limitu środków, na podstawie wniosków nabywców lokali przekazanych do BGK, wynosi ponad $231 \mathrm{mln}$ zł, z czego ponad $176 \mathrm{mln}$ zł dotacji przypada na 2014 rok. Kwota ta stanowi 29,45\% środków przeznaczonych na rok 2014. Przy zachowaniu bie-

1 https://rodzina.gov.pl/mieszkanie/program-mieszkanie-dla-mlodych

2 http://www.bgk.com.pl/mieszkanie-dla-mlodych/komunikaty-w-bip 
Wykres 1 . Wysokość wskaźników cen za $1 \mathrm{~m}^{2}$ mieszkania w Warszawie, gminach przylegających i pozostałych miastach województwa mazowieckiego w poszczególnych kwartach 2014 roku (w PLN)

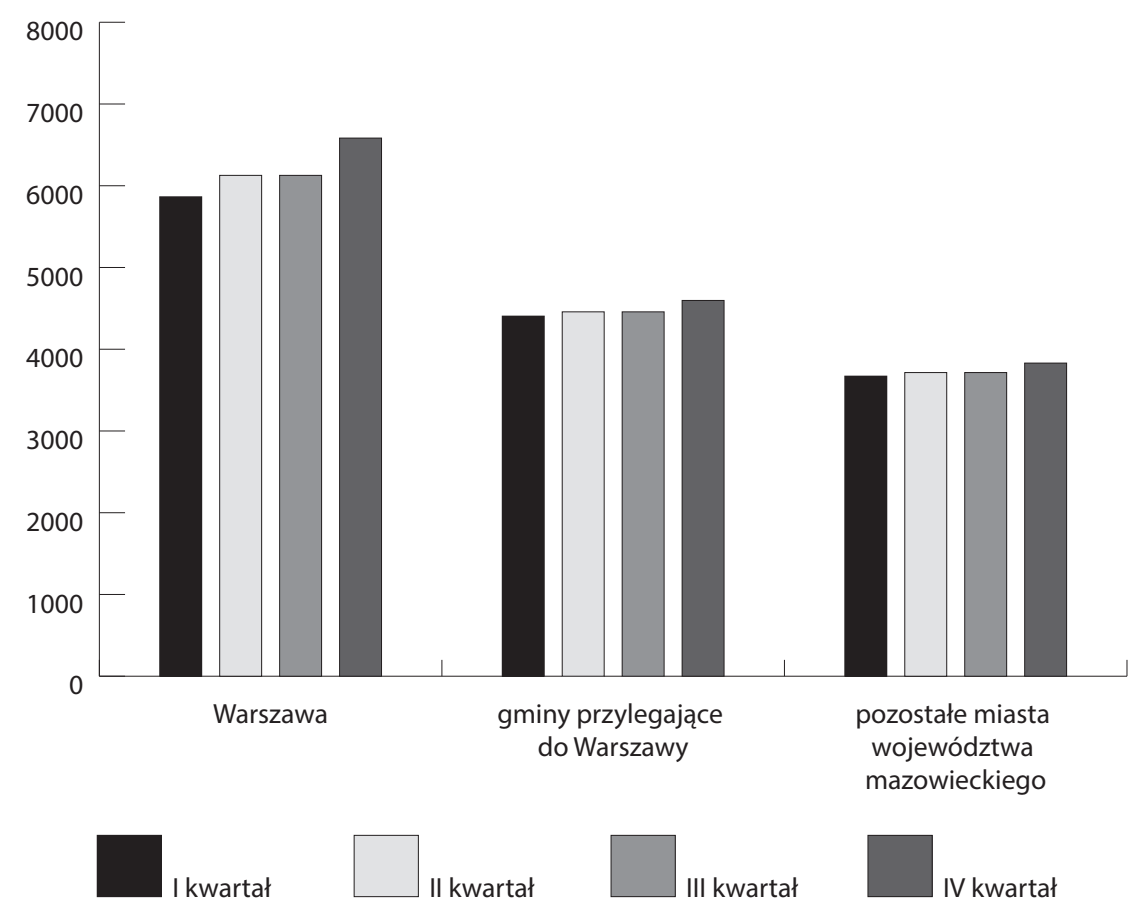

Opracowanie własne na podstawie danych $\mathrm{z}$ http://www.bgk.com.pl/mieszkanie-dla-mlodych/ komunikaty-w-bip.

żącej dynamiki wartość wykorzystanych środków w obecnym roku nie powinna przekroczyć $60 \%$ dostępnych środków. Jest to o tyle istotne, że tegoroczna pula nie zostanie przeniesiona na kolejne lata. Idąc dalej, Bank Gospodarstwa Krajowego zarezerwował już ponad $50 \mathrm{mln}$ zł na dopłaty w 2015 roku, co stanowi z kolei 7,04\% środków przeznaczonych na przyszły rok. Oznacza to niestety, że jeżeli dynamika programu zostanie utrzymana, pod koniec przyszłego roku może zabraknąć środków na dopłaty ${ }^{3}$.

Inną formą wsparcia finansowego rodzin, który zasługuje na wspomnienie, jest program polegający na dofinansowaniu do kredytów na budowę domów energooszczędnych. Zgodnie z dyrektywą Parlamentu Europejskiego i Rady

3 http://mieszkaniedlamlodych.com/program-mieszkanie-dla-mlodych-podsumo wanie-po-8-miesiacach-dzialania/ 
Europy 2010/31/UE z dnia 19 maja 2010 roku w sprawie charakterystyki energetycznej budynków państwa członkowskie zostały zobowiązane do doprowadzenia do tego, aby od początku 2021 roku wszystkie nowo powstające budynki były obiektami „o niemal zerowym zużyciu energii”. Jest to pierwszy ogólnopolski instrument wsparcia dla budujących budynki mieszkalne o niskim zużyciu energii. Ma stanowić dla nich impuls do zmiany sposobu budowania oraz przygotować inwestorów, projektantów, producentów materiałów budowlanych, wykonawców do wymagań Dyrektywy. Program skierowany jest do osób fizycznych, które budują dom jednorodzinny lub kupują dom/mieszkanie od dewelopera. Dotacja ma formę częściowej spłaty kapitału kredytu wziętego na budowę bądź zakup domu czy też zakup mieszkania. Dofinansowanie przyznawane będzie po zakończeniu realizacji przedsięwzięcia oraz potwierdzeniu uzyskania przez budynek wymaganego standardu energetycznego. Budżet programu wynosi $300 \mathrm{mln}$ zł. Na lata 2013-2015 przewidziano dopłaty w wysokości $1 \frac{1}{3}$ przeznaczonego budżetu, reszta kwoty przekazana została na dofinansowania w latach 2016-2018. Dotychczas brak jest danych o tym, ile zgłoszono wniosków o dotację w tym programie i jaki jest w tym udział województwa mazowieckiego ${ }^{4}$.

Jedną z podstawowych form pomocy finansowej rodzinom są dodatki mieszkaniowe przeznaczone na utrzymanie posiadanego lub wynajmowanego mieszkania czy też domu jednorodzinnego. Z takiego dodatku mogą skorzystać osoby, które znajdują się w trudnej sytuacji materialnej i spełniają kryteria, w tym dochodowe ${ }^{5}$. Średni miesięczny dochód na jednego członka gospodarstwa domowego w okresie trzech miesięcy poprzedzających datę złożenia wniosku o przyznanie dodatku mieszkaniowego nie może przekraczać 175\% najniższej emerytury w gospodarstwie jednoosobowym i 125\% w gospodarstwie wieloosobowym. Dodatek mieszkaniowy można otrzymać pod warunkiem, że lokal mieszkalny jest dostosowany wielkością do liczby osób w gospodarstwie domowym ${ }^{6}$. W województwie mazowieckim w 2013 roku dodatki mieszkaniowe udzielono dla 67637 osób, którym przyznano 375312 świadczeń na łącz-

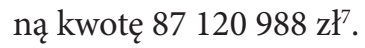

Rodziny, które mają dzieci, już od chwili pojawienia się dziecka mogą korzystać z różnego rodzaju świadczeń związanych z posiadaniem dziecka, mię-

4 https://rodzina.gov.pl/mieszkanie/doplaty-do-kredytow-do-budowy-domowenergooszczednych

5 https://rodzina.gov.pl/mieszkanie/dodatki-mieszkaniowe

6 https://rodzina.gov.pl/sites/default/files/pliki_do_pobrania/dodatki_mieszka niowe_-_do_pobrania.pdf

7 Ocena zasobów pomocy społecznej w oparciu o sytuację społeczna i demograficzna Województwa Mazowieckiego za 2013 rok, s. 24; http://www.mazovia.pl/downloadStat/gfx/ mazovia/pl/mazoviauchwalysejmiku/59/2801/1/zalacznik.docx 
dzy innymi z becikowego, zasiłku rodzinnego. Dodatkowe świadczenia przysługują dzieciom niepełnosprawnym i ich opiekunom.

Tabela 2. Liczba oraz łączna wysokość przyznanych świadczeń w województwie mazowieckim w 2013 roku

\begin{tabular}{|l|c|c|}
\hline \multicolumn{1}{|c|}{ Rodzaj świadczenia } & $\begin{array}{c}\text { Liczba przyznanych } \\
\text { świadczeń }\end{array}$ & $\begin{array}{c}\text { Lączna wysokość świadczeń } \\
\text { (w zł) }\end{array}$ \\
\hline $\begin{array}{l}\text { Jednorazowa zapomoga } \\
\text { z tytułu urodzenia się } \\
\text { dziecka - becikowe }\end{array}$ & 77779 & 34734900 \\
\hline $\begin{array}{l}\text { Jednorazowy dodatek } \\
\text { z tytułu urodzenia się } \\
\text { dziecka }\end{array}$ & 6811 & 15004300 \\
\hline $\begin{array}{l}\text { Zasiłek rodzinny } \\
\text { i dodatki do niego }\end{array}$ & 237304 & 506592808 \\
\hline
\end{tabular}

Opracowanie własne na podstawie: Ocena zasobów pomocy społecznej w oparciu o sytuację społeczną i demograficzną województwa mazowieckiego za 2013 rok, s. 24.

Tabela 2. przedstawia informacje dotyczące liczby oraz łącznej wysokości świadczeń przyznanych w województwie mazowieckim w 2013 roku. Z informacji w niej zawartych wynika, że jednorazową zapomogę z tytułu urodzenia się dziecka - becikowe - w 2013 roku przyznano w postaci 77779 świadczeń na łączną kwotę 34734900 zł. Z kolei rodzinom, które kwalifikują się do korzystania z zasiłku rodzinnego, przyznano jednorazowy dodatek z tytułu urodzenia się dziecka. Z tego tytułu przyznano 6811 świadczeń na łączną kwotę 15004300 zł. Zasiłek rodzinny i dodatek do niego wypłacono dla 237304 rodzin na łączną kwotę 506592808 zł.

Tabela 3. zawiera dane dotyczące liczby rodzin otrzymujących zasiłki rodzinne na dzieci oraz liczbę dzieci, na które został przyznany rodzicom zasiłek rodzinny w poszczególnych powiatach województwa mazowieckiego w latach 20112013. Z danych tych wynika, że najwięcej rodzin korzystających w 2013 roku z pomocy w postaci zasiłków rodzinnych zamieszkiwało powiaty radomski, miasto stołeczne Warszawa, powiat wołomiński. Z kolei najmniej rodzin będących beneficjentami pomocy było w powiatach: warszawskim zachodnim, grodziskim oraz łosickim. W 2013 roku liczba dzieci, na które rodzice otrzymują zasiłek rodzinny, była największa w powiatach radomskim, mieście stołecznym Warszawa oraz w mieście Radom. Z kolei najmniejszą liczbą dzieci, na które został rodzicom przyznany zasiłek, charakteryzowały się powiaty warszawski zachodni, miasto Ostrołęka oraz powiat lipski. W latach 2011-2013 obserwowana 
jest tendencja spadkowa, co oznacza, że liczba rodzin otrzymujących zasiłki rodzinne oraz liczba dzieci, na które rodziny otrzymują zasiłek, uległa zmniejszeniu.

Tabela 3. Liczba rodzin otrzymujących zasiłki rodzinne oraz liczba dzieci, na które rodziny otrzymują zasiłek w powiatach województwa mazowieckiego w latach 2011-2013

\begin{tabular}{|l|c|c|c|c|c|c|}
\hline \multirow{2}{*}{ Jednostka terytorialna } & \multicolumn{3}{|c|}{$\begin{array}{r}\text { Rodziny otrzymujące zasiłki } \\
\text { rodzinne na dzieci }\end{array}$} & \multicolumn{3}{c|}{$\begin{array}{c}\text { Dzieci, na które rodzice } \\
\text { otrzymujáłem rodzinny - }\end{array}$} \\
\cline { 2 - 7 } & 2011 & 2012 & 2013 & 2011 & 2012 & 2013 \\
\hline Powiat ciechanowski & 3809 & 3474 & 3205 & 7439 & 6782 & 6276 \\
\hline Powiat gostyniński & 2078 & 1882 & 1780 & 4154 & 3787 & 3548 \\
\hline Powiat mławski & 4444 & 4046 & 3805 & 9054 & 8217 & 7643 \\
\hline Powiat płocki & 5270 & 4799 & 4613 & 10678 & 9679 & 9103 \\
\hline Powiat płoński & 4429 & 4080 & 3805 & 8750 & 8067 & 7495 \\
\hline Powiat sierpecki & 3421 & 3175 & 2945 & 6815 & 6306 & 5786 \\
\hline Powiat żuromiński & 3096 & 2879 & 2657 & 6083 & 5664 & 5235 \\
\hline Powiat m. Płock & 2817 & 2552 & 2571 & 5148 & 4683 & 4610 \\
\hline Powiat łosicki & 1881 & 1723 & 1620 & 3906 & 3594 & 3317 \\
\hline Powiat makowski & 3011 & 2843 & 2707 & 6119 & 5742 & 5379 \\
\hline Powiat ostrołęcki & 6575 & 6181 & 5876 & 14232 & 13252 & 12522 \\
\hline Powiat ostrowski & 4019 & 3661 & 3434 & 8223 & 7547 & 6986 \\
\hline Powiat przasnyski & 3423 & 3190 & 2986 & 7133 & 6679 & 6192 \\
\hline Powiat pułtuski & 2539 & 2368 & 2325 & 5153 & 4776 & 4633 \\
\hline Powiat siedlecki & 4614 & 4247 & 3964 & 10078 & 9195 & 8448 \\
\hline Powiat sokołowski & 2440 & 2172 & 1967 & 5098 & 4573 & 4099 \\
\hline Powiat węgrowski & 3638 & 3390 & 3172 & 7517 & 6994 & 6541 \\
\hline Powiat wyszkowski & 3750 & 3469 & 3320 & 7727 & 7148 & 6834 \\
\hline Powiat m. Ostrołęka & 1903 & 1747 & 1637 & 3448 & 3166 & 2983 \\
\hline Powiat m. Siedlce & 2198 & 1979 & 1840 & 4122 & 3799 & 3570 \\
\hline Powiat białobrzeski & 2208 & 2088 & 1950 & 4623 & 4294 & 3981 \\
\hline Powiat kozienicki & 2819 & 2662 & 2494 & 5628 & 5271 & 4879 \\
\hline Powiat lipski & 2023 & 1827 & 1702 & 3979 & 3602 & 3285 \\
\hline Powiat przysuski & 3101 & 2848 & 2684 & 6060 & 5585 & 5237 \\
\hline
\end{tabular}




\begin{tabular}{|c|c|c|c|c|c|c|}
\hline \multirow[t]{2}{*}{ Jednostka terytorialna } & \multicolumn{3}{|c|}{$\begin{array}{l}\text { Rodziny otrzymujące zasiłki } \\
\text { rodzinne na dzieci }\end{array}$} & \multicolumn{3}{|c|}{$\begin{array}{c}\text { Dzieci, na które rodzice } \\
\text { otrzymują zasiłek rodzinny - } \\
\text { ogółem }\end{array}$} \\
\hline & 2011 & 2012 & 2013 & 2011 & 2012 & 2013 \\
\hline Powiat radomski & 10137 & 9261 & 8685 & 20506 & 18968 & 17645 \\
\hline Powiat szydłowiecki & 2803 & 2594 & 2379 & 5484 & 5064 & 4637 \\
\hline Powiat zwoleński & 2464 & 2272 & 2113 & 4941 & 4559 & 4239 \\
\hline Powiat m. Radom & 8627 & 7667 & 7385 & 15467 & 13912 & 13392 \\
\hline Powiat m. st. Warszawa* & 12851 & 12075 & 11950 & 24266 & 22912 & 22722 \\
\hline Powiat garwoliński & 5440 & 5003 & 4751 & 11836 & 10842 & 10087 \\
\hline Powiat legionowski & 2146 & 2004 & 1895 & 4155 & 3904 & 3740 \\
\hline Powiat miński* & 5008 & 4674 & 4591 & 10216 & 9558 & 9338 \\
\hline Powiat nowodworski & 2680 & 2441 & 2200 & 5300 & 4817 & 4411 \\
\hline Powiat otwocki & 3021 & 2701 & 2576 & 5968 & 5416 & 5078 \\
\hline Powiat wołomiński & 6770 & 6212 & 6039 & 13566 & 12556 & 12143 \\
\hline Powiat grodziski & 1803 & 1651 & 1617 & 3716 & 3390 & 3299 \\
\hline Powiat grójecki* & 3962 & 3643 & 3392 & 7915 & 7209 & 6649 \\
\hline Powiat piaseczyński* & 2510 & 2299 & 2270 & 5130 & 4745 & 4589 \\
\hline Powiat pruszkowski & 2031 & 1889 & 1830 & 3913 & 3668 & 3596 \\
\hline Powiat sochaczewski & 3102 & 2826 & 2688 & 6095 & 5571 & 5303 \\
\hline $\begin{array}{l}\text { Powiat warszawski } \\
\text { zachodni }\end{array}$ & 1761 & 1631 & 1521 & 3493 & 3213 & 3003 \\
\hline Powiat żyrardowski & 2411 & 2136 & 2001 & 4759 & 4262 & 3979 \\
\hline
\end{tabular}

Opracowanie własne na podstawie danych GUS; http://stat.gov.pl/bdl/app/dane_podgrup. display?p_id=997053\&p_token $=0.7730416031554341$

Tabela 4. przedstawia informacje dotyczące liczby oraz łącznej wysokości świadczeń przyznanych osobom niepełnosprawnym $\mathrm{i}$ ich opiekunom w województwie mazowieckim w 2013 roku. Z informacji w niej zawartych wynika, że zasiłek pielęgnacyjny dla:

- niepełnosprawnego dziecka wypłacono 52518 osobom na łączną kwotę 48307394 zł,

- osób niepełnosprawnych w wieku powyżej 16. roku życia o znacznym stopniu niepełnosprawności wypłacono 79944 osobom w łącznej wysokości 68969040 zł, 
- osób niepełnosprawnych w wieku powyżej 16. roku życia o umiarkowanym stopniu niepełnosprawności powstałej przed ukończeniem 21. roku życia wypłacono 46116 osobom na łączną kwotę 46743839 zł.

Świadczenie pielęgnacyjne (przysługujące matce albo ojcu, opiekunowi faktycznemu dziecka, osobie będącej rodziną zastępczą spokrewnioną oraz innym osobom, na których ciąży obowiązek alimentacyjny, jeżeli nie podejmują lub rezygnują z zatrudnienia lub innej pracy zarobkowej w celu sprawowania opieki nad osobą legitymującą się orzeczeniem o niepełnosprawności) zostało udzielone 29956 osobom w łącznej kwocie 119440112 zł.

Tabela 4. Liczba oraz łączna wysokość świadczeń przyznanych osobom niepełnosprawnym i ich opiekunom w województwie mazowieckim w 2013 roku

\begin{tabular}{|l|c|c|}
\hline Rodzaj świadczenia & $\begin{array}{c}\text { Liczba przyznanych } \\
\text { świadczeń }\end{array}$ & $\begin{array}{c}\text { Lączna wysokość } \\
\text { świadczeń (w zł) }\end{array}$ \\
\hline $\begin{array}{l}\text { Zasiłek pielęgnacyjny dla } \\
\text { niepełnosprawnego dziecka }\end{array}$ & 52518 & 48307394 \\
\hline $\begin{array}{l}\text { Zasiłek pielęgnacyjny dla osoby } \\
\text { niepełnosprawnej w wieku powyżej 16. rż. } \\
\text { o znacznym stopniu niepełnosprawności }\end{array}$ & 79944 & 68969040 \\
\hline $\begin{array}{l}\text { Zasiłek pielęgnacyjny dla osoby } \\
\text { niepełnosprawnej w wieku } \\
\text { pow. 16. rż. o umiarkowanym stopniu } \\
\text { niepełnosprawności }\end{array}$ & 46116 & 46743839 \\
\hline Świadczenie pielęgnacyjne & 29956 & 119440112 \\
\hline
\end{tabular}

Opracowanie własne na podstawie: Ocena zasobów pomocy społecznej w oparciu o sytuację społeczną i demograficzną województwa mazowieckiego za 2013 rok, s. 24.

Pomoc z funduszu alimentacyjnego udzielana jest dzieciom, których rodzic nie płaci zasądzonych alimentów, i maksymalnie może wynieść 500 zł miesięcznie.

Do form pomocy finansowej przyznawanej rodzinom zalicza się również Karty Dużej Rodziny, które przysługują rodzinom z przynajmniej trójką dzieci, niezależnie od dochodu. Taką kartę przyznaje wójt, burmistrz lub prezydent miasta na wniosek członka rodziny wielodzietnej. W województwie mazowieckim powstało najwięcej, bo aż 15 kart samorządowych. Niestety największy ośrodek, czyli miasto Warszawa, nie wprowadziło tej możliwości, stąd tylko 9\% ludności $\mathrm{w}$ województwie jest objęta jej działaniem ${ }^{8}$. W województwie mazowieckim do

8 Karty Dużych Rodzin w polskich samorządach - raport Związku Dużych Rodzin 3+, Warszawa, marzec 2013, s. 7; http://kartaduzejrodziny.3plus.pl/raporty/raport/ 
Wykres 2. Liczba osób korzystający ze świadczeń z funduszu alimentacyjnego oraz liczba rodzin, którym przyznano świadczenie w województwie mazowieckim w latach 2011-2013

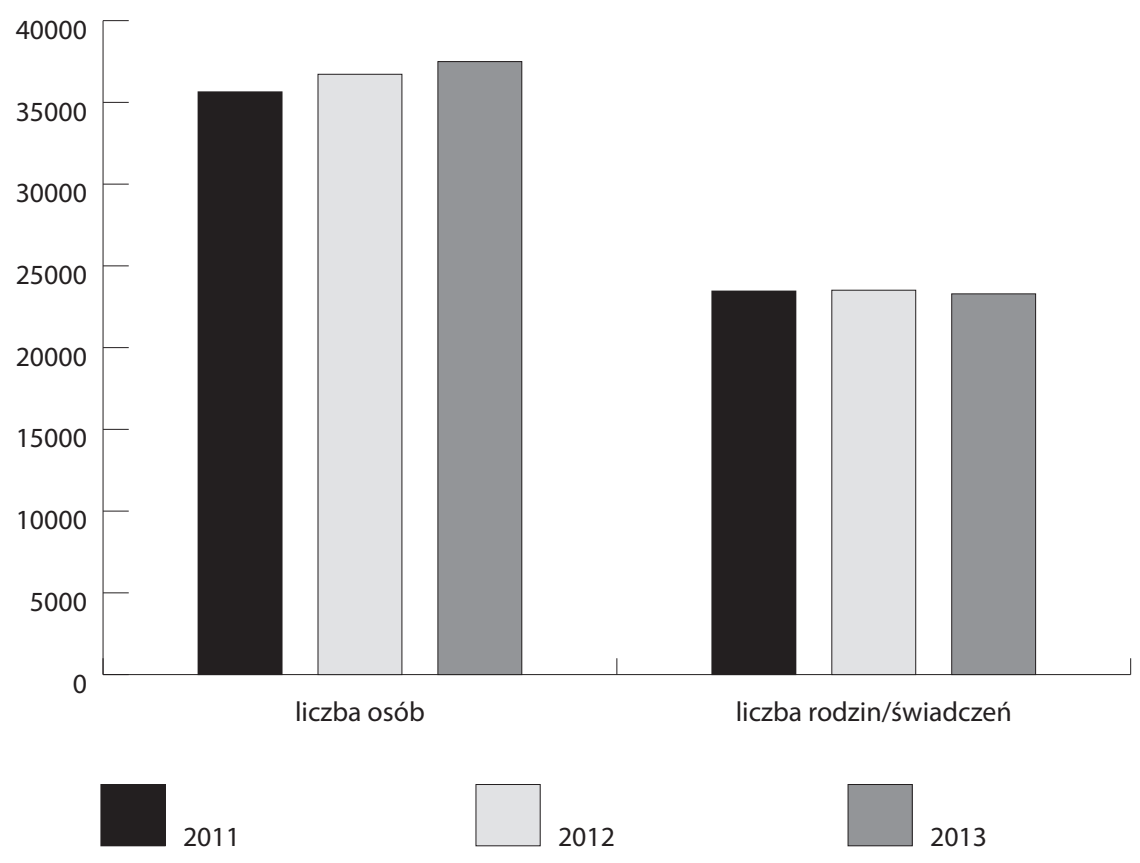

Opracowanie własne na podstawie: Ocena zasobów pomocy społecznej w oparciu o sytuację społeczną i demograficzną województwa mazowieckiego za 2013 rok, s. 53.

programu przystąpiły następujące miasta i gminy: Błonie, Ciechanów, Garwolin, Góra Kalwaria, Grodzisk Mazowiecki, Izabelin, Jabłonna, Jaktorów, Klembów, Konstancin-Jeziorna, Kozienice, Legionowo, Lesznowola, Łomianki, Marki, Milanówek, Mińsk Mazowiecki, Mława, Mszczonów, Nieporęt, Nowa Sucha, Nowy Dwór Mazowiecki, Ostrołęka, Otwock, Ożarów Mazowiecki, Piaseczno, powiat wołomiński, Płock, Płońsk, Pułtusk, Radom, Radziejowice, Rzekuń, Serock, Siedlce, Sochaczew, Sokołów Podlaski, Teresin, Węgrów, Wieliszew, Wołomin, Wyszków, Zielonka, Zwoleń Żabia Wola9

W województwie mazowieckim jest 1327 stołówek mieszczących się w szkołach o różnych profilach. Ze stołówek tych korzysta 209109 osób. W województwie mazowieckim odsetek uczniów spożywających posiłek w szkolnej stołów-

9 http://www.3plus.pl/samorzadowe-karty-duzej-rodziny,k68.html 
Wykres 3. Infrastruktura społeczna w województwie mazowieckim w latach 2011-2013

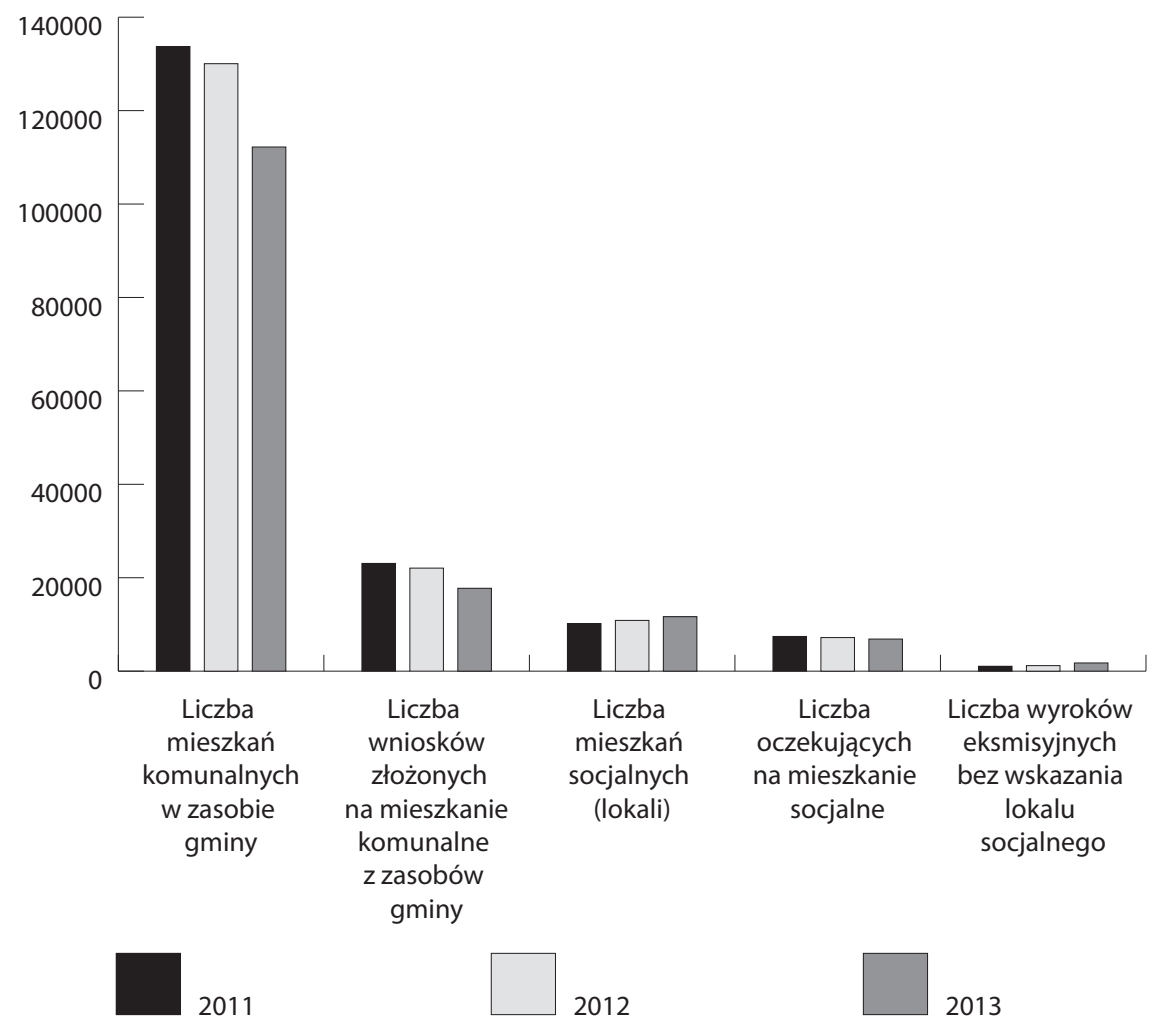

Opracowanie własne na podstawie: Ocena zasobów pomocy społecznej w oparciu o sytuację społeczną i demograficzną województwa mazowieckiego za 2013 rok, s. 15.

ce jest na poziomie około 30\%. Jest to średni wynik na tle innych województw. Gminy i miasta finansują posiłki części uczniów, w województwie mazowieckim uczniowie, którzy spożywają nieodpłatne posiłki, stanowią 16,6 proc. uczniów. Według badań Polskiej Akcji Humanitarnej zapotrzebowanie na refundację posiłków jest większe - takiej pomocy potrzebuje dodatkowo 10,3 proc. wszystkich uczniów w województwie mazowieckim. W ramach programu „Pomoc państwa w zakresie dożywiania” w województwie mazowieckim przyznano zasiłki celowe 35504 osobom na łączną kwotę 18006982 zł'10.

Przez pomoc materialną ze strony państwa należy tu rozumieć zarówno wszelkie usługi, z których mogą korzystać rodziny, jak i pracę socjalną.

10 Ocena zasobów pomocy społecznej..., dz. cyt., s. 22. 
Rodziny, które mają niskie dochody, mogą liczyć na pomoc ze strony gmin polegającą na dofinansowaniu lokali komunalnych, socjalnych oraz zastępczych. Pomoc ze strony gmin jest związana z obowiązkiem planowania i realizacji działań zmierzających do tworzenia warunków do zaspokajania potrzeb mieszkaniowych wspólnoty samorządowej.

Wykres 3. przedstawia stan infrastruktury społecznej w województwie mazowieckim w latach 2011-2013. Z informacji zawartych w wykresie 3. wynika, że gminy województ wa mazowieckiego posiadały w 2013 roku w swoich zasobach 112213 mieszkań komunalnych oraz 11660 mieszkań socjalnych. Liczba wniosków złożonych na mieszkanie komunalne wyniosła 17 742, zaś 6873 osoby oczekiwały na mieszkania socjalne. Z analizy danych w latach 2011-2013 wynika, że gminy mają mniej mieszkań komunalnych (ich liczba w 2013 roku w stosunku do 2011 roku zmniejszyła się o 21513 lokali). Z kolei liczba mieszkań socjalnych w porównaniu z 2011 roku wzrosła o 1474 mieszkania. Zarówno w przypadku mieszkań komunalnych, jak i socjalnych można zaobserwować zmniejszenie się liczby wniosków o przyznanie takiego mieszkania. Należy też zauważyć, że w latach 2011-2013 nastąpił wzrost liczby wyroków eksmisyjnych bez wskazania lokalu socjalnego i wyniósł on 1757 eksmisji (wzrost w stosunku do 2011 roku o 711 takich zdarzeń) ${ }^{11}$.

Rodzice posiadający dzieci mogą liczyć na pomoc ze strony państwa w opiece nad dziećmi między innymi w takich instytucjach, jak żłobki, kluby dziecięce, przedszkola.

Tabela 5. Stan infrastruktury społecznej w województwie mazowieckim w latach 2011-2013

\begin{tabular}{|l|r|r|r|}
\hline \multicolumn{1}{|c|}{ Wyszczególnienie } & \multicolumn{1}{c|}{2011} & \multicolumn{1}{c|}{2012} & \multicolumn{1}{c|}{2013} \\
\hline Liczba żłobków & 99 & 123 & 167 \\
\hline Liczba opiekunów dziennych do dzieci & 3 & 6 & 28 \\
\hline Liczba miejsc w żłobkach & 6151 & 6630 & 8341 \\
\hline Liczba przedszkoli & 2341 & 2444 & 2814 \\
\hline Liczba miejsc w przedszkolach & 151874 & 158813 & 175549 \\
\hline
\end{tabular}

Opracowanie własne na podstawie: Ocena zasobów pomocy społecznej w oparciu o sytuację społeczną i demograficzną województwa mazowieckiego za 2013 rok, s. 15.

11 Tamże, s.15. 
Wykres 4. Liczba osób korzystających z pomocy społecznej i wsparcia w województwie mazowieckim w latach 2011-2013

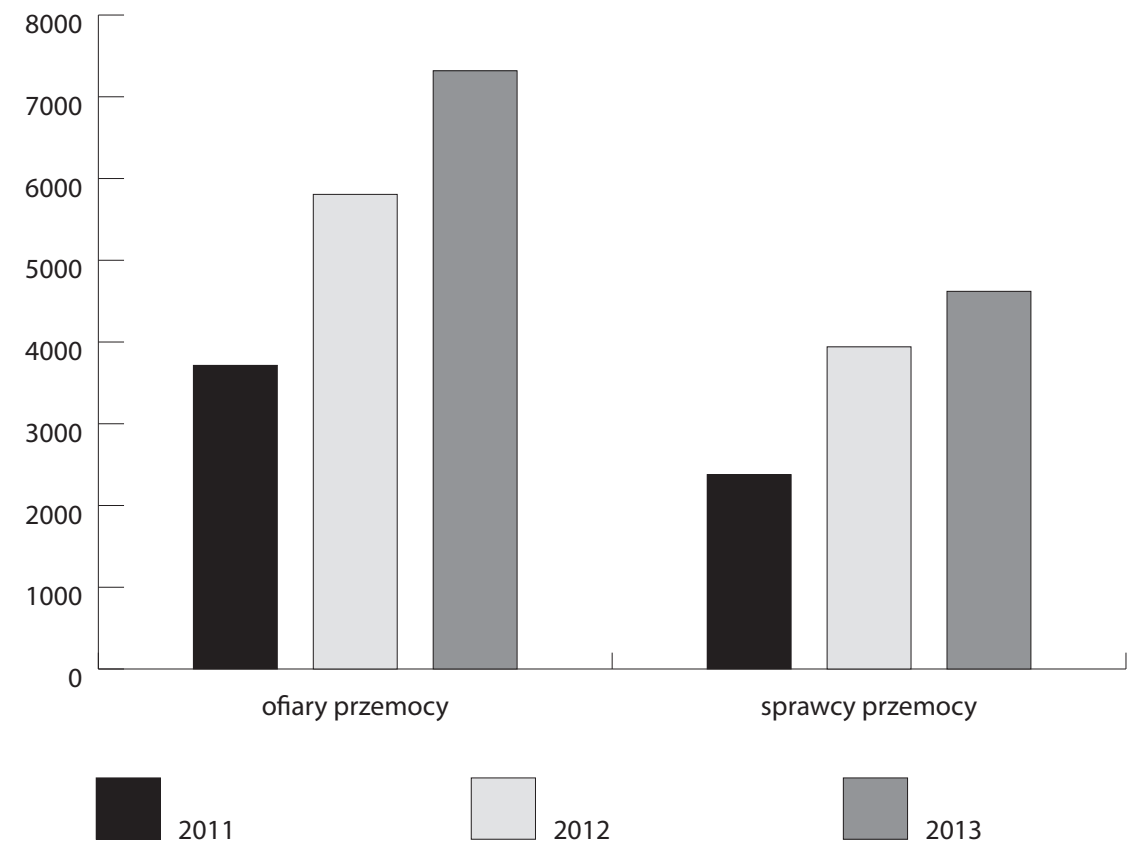

Opracowanie własne na podstawie: Ocena zasobów pomocy społecznej w oparciu o sytuację społeczną i demograficzną województwa mazowieckiego za 2013 rok, s. 49.

Analizując pomoc rodzinie, nie można pominąć działań jednostek organizacyjnych pomocy społecznej. Jednostki te pomoc realizują również poprzez ochronę rodziny przed przemocą.

Wykres 4. przedstawia zmianę liczby osób korzystających pomocy społecznej i wsparcia w latach 2011-2013 W 2013 roku udzielono pomocy 7318 osobom będącym ofiarami przemocy w rodzinie. Z pomocy społecznej skorzystali również sprawcy przemocy rodzinnej, było to 4620 osób.

W miastach i powiatach wraz z m. st. Warszawa pomocy udzielono 567 rodzinom będącym ofiarami przemocy domowej i 214 sprawcom przemocy. $\mathrm{W}$ miastach na prawach powiatu udzielono pomocy 784 rodzinom i ofiarom przemocy domowej oraz 648 sprawcom. Jednostki samorządu terytorialnego na przeciwdziałanie przemocy rodzinie w 2013 roku przeznaczyły 1453901 zł, a jednostki organizacyjne pomocy społecznej - $812101 \mathrm{zf}^{12}$.

12 Tamże, s.55. 
Analizując zakres wsparcia pomocy społecznej oferowanym rodzinom wielodzietnym i niepełnym w województwie mazowieckim, należy chociaż wspomnieć o programach wspierających rodziny. Mają mieć zasięg ogólnokrajowy, powiatowy czy też gminny. Stanowią one ważne uzupełnienie do oferowanej pomocy materialnej i finansowej.

\section{Bibliografia}

\section{Raporty}

Karty Dużych Rodzin w polskich samorządach - raport Związku Dużych Rodzin 3+, Warszawa marzec 2013; http://kartaduzejrodziny.3plus.pl/raporty/raport/ (24.05.2015).

Ocena zasobów pomocy społecznej w oparciu o sytuację społeczną i demograficzną Województwa Mazowieckiego za 2013 rok; Załącznik do uchwały Nr 184/14 Sejmiku Województwa Mazowieckiego z dnia 7 lipca 2014 roku, http://www.mazovia.pl/download Stat/gfx/mazovia/pl/mazoviauchwalysejmiku/59/2801/1/zalacznik.docx (24.05.2015).

\section{Strony internetowe}

https://rodzina.gov.pl/sites/default/files/pliki_do_pobrania/dodatki_mieszkaniowe_-_do_ pobrania.pdf wydruk 24.05.2015r.

https://rodzina.gov.pl/mieszkanie/program-mieszkanie-dla-mlodych. (24.05.2015).

http://www.bgk.com.pl/mieszkanie-dla-mlodych/komunikaty-w-bip. (24.05.2015).

http://mieszkaniedlamlodych.com/program-mieszkanie-dla-mlodych-podsumowanie-po-8miesiacach-dzialania/ (24.05.2015).

https://rodzina.gov.pl/mieszkanie/doplaty-do-kredytow-do-budowy-domow-energo oszczednych. (24.05.2015).

https://rodzina.gov.pl/mieszkanie/dodatki-mieszkaniowe (24.05.2015).

http://stat.gov.pl/bdl/app/dane_podgrup.display?p_id=997053\&p_token=0.7730416031

554341. (24.05.2015).

http://www.3plus.pl/samorzadowe-karty-duzej-rodziny,k68.html. (24.05.2015). 